\title{
The student record cards of the Lincoln Diocesan Training College: A genealogical and demographic evaluation for the periods 1862-1871 and 1892- 1901.
}

Received: 31 October 2020 Accepted: 28 November 2020

Keywords: Elementary; teacher-training; pupil teacher; parchment

\section{Colin Dykes}

\begin{abstract}
The Lincoln Diocesan Training College (LDTC), now Bishop Grosseteste University (BGU), trained women as elementary school teachers. The student records, in the form of handwritten cards, are located in the BGU archives. This study set out to determine the genealogical value of these records. To this end, a sample of the records for 1862-1871 and 1892-1901 were examined and compared. ${ }^{1}$ The two periods cover the first ten years of the first and second principals' respective tenures at LDTC. A study of the genealogical information on the cards, for both periods, showed that there were very few serious discrepancies between this information and online genealogical records. In addition, many of the cards provide information that would not normally be found in other genealogical sources. Other online teacher records collections were analysed for information relating to the individuals in the two samples and found to apply to a very small group of LDTC teachers. The demographic analysis of the students was compared to other teacher-related studies. The differences between some of the findings for the two periods, like marriage age and probate effects, were found to be significant.
\end{abstract}

\section{Introduction}

LDTC was one of sixty-one teacher training colleges that were established in the nineteenth century with the intention of training elementary school teachers to educate working class children. Of these training colleges, 20 were for men, 30 for women and 11 were co-educational. Residential colleges accounted for 45 of the institutions and the rest were day training. Of the residential colleges, 6 belonged to the British and Foreign School Society (BFSS), 2 were un-denominational, 2 Wesleyan, 3 Roman Catholic and 32 Church of England. ${ }^{2}$ The first Church of England Colleges were established by the National Society for promoting the Education of the Poor in the Principles of the Established Church throughout England and Wales (National Society). Thereafter, the Diocesan authorities became involved in establishing colleges as more statefunded assistance became available. The National and Diocesan colleges provided trained teachers for National or Church schools. With respect to these different categories, LDTC (Figure 1) was established in 1862 as a Diocesan residential training college for women.

In 1870, the Forster Act introduced state elementary schools run by local Boards known as Board Schools. Although these schools were only set up in areas where the National Society and the BFSS were failing to provide a suitable education, this Act is sometimes regarded as marking the beginning of a state controlled system of compulsory elementary education. ${ }^{345}$

In 1902, all voluntary and state controlled educational institutions were brought under the control of Local Education Authorities (LEA). The LEAs were empowered to establish training colleges and paved the way to helping overcome the then shortfall in trained teachers. This also ended the voluntary organisations' dominance of this sector. ${ }^{6}$

The LDTC students' first school appointments reflected this historical context. For the period 1862-1871, students were appointed to 'National' or 'Church' schools whereas a significant number of students from 1892-1901 were appointed to Board schools. The students from LDTC, who were working as teachers during the 1911 census, were recorded as working for a local council which reflects the control of LEA's established in 1902.

( 2021 The Author(s). This is an open access article distributed under the terms of the Creative Commons Attribution License (http://creativecommons.org/ licenses/by/4.0/) 


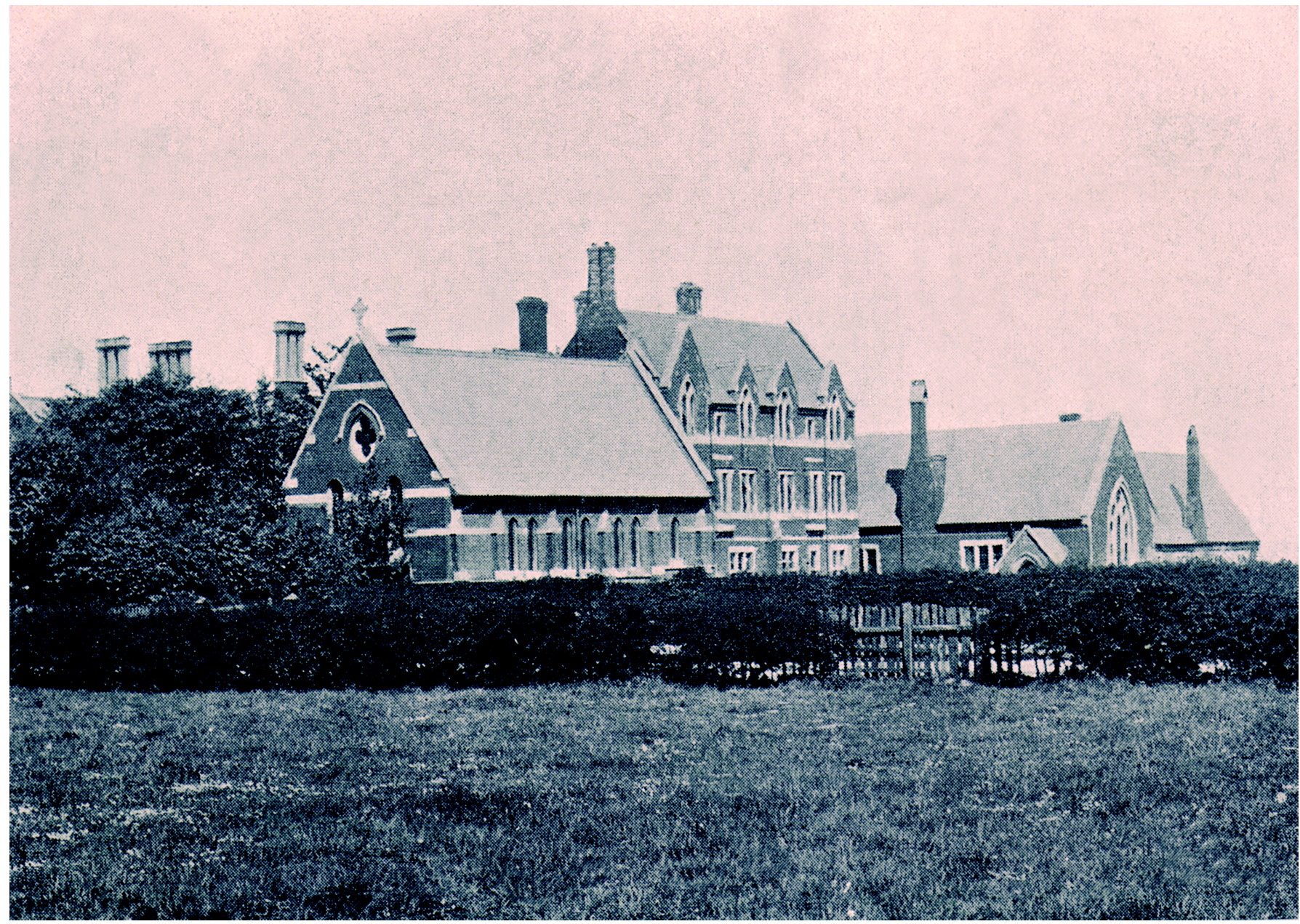

Figure 1. South West View of the Lincoln Diocesan College c.1897.' Photograph used with the permission of the Bishop Grosseteste Archives.

\section{Training to be an elementary school teacher}

Nearly all of the LDTC students for the two periods were pupil teachers prior to attending the College. Dr James Philip Kay (later Kay-Shuttleworth), the first secretary of the Privy Council on Education, introduced this concept of teacher provision in 1846. Under this system, the brightest and most promising pupils, at the age of thirteen, were apprenticed to the head teacher for five years. During this time, they would serve as teachers during the day and receive instruction for an hour and a half out of school hours. The pupil was not obliged to become a teacher at the end of this period but, if they wanted to become teachers, they had a number of options open to them. They could sit the Queen's Scholarship examination which, if they passed, entitled them to a grant, ranging from $£ 20$ to $£ 25$, to continue their studies at a training college, in addition to a yearly grant of $£ 30$ p.a. for each trainee going to the college for up to three years of study. ${ }^{8}$ Alternately, pupil teachers were also able to become assistant teachers or provisionally certificated teachers if they wanted to continue with teaching on the completion of their apprenticeship. ${ }^{9}$

In addition to the training college education the students received, they also underwent a probationary period. If they received two favourable inspection reports in a row, while they were at the same school, they were awarded their parchment and could negotiate better salaries. For each award the training college also received a $£ 75$ grant paid in instalments over five years. ${ }^{10}{ }^{11}$ There was, therefore, an incentive for the college principals to see their graduates achieve their parchment. Canon Nelson's concerns in this regard were particularly evident on the student cards. He saw marriage as a particular threat to a graduate achieving her parchment. One of a number of clear examples of this concern, led to him to compile a contract for all students to sign emphasising the importance of the matter. The details were written onto Martha William's card (she did achieve her parchment despite Nelson's misgivings): ${ }^{12}$

'...she did not get her Parchment in [18]66 and is now married. A notion was abroad among the students of this class quite unfounded that they were to teach two years in their schools and then to be at liberty to do what they liked. I have corrected this statement by a paper which they all SIGN to the effect that if they abandon the profession before gaining parchment they will do a dishonest thing.' 
A version of the 'paper' was included in the principal's submission to the Cross Commission of $1888:^{13}$

I, the undersigned, accept the offer of being trained at this institution, binding myself to stay two years with the knowledge that if this engagement is broken, the Committee of Council will not grant me a certificate. I have filled up and signed Form 35D. I also engage not to leave my first school until I have gained my parchment, except for causes approved by the Principal; and I hereby acknowledge that should I desert the profession of schoolmistress in a Government school without having obtained my parchment, or paying 70l, to the training school, I shall be doing a dishonest thing.'

\section{The extent of teacher-training records}

The evidence suggests that training college records are a significant data source. Table 1 shows that there were just over 36,000 certificated college-trained teachers working in England and Wales in $1899 .{ }^{14}$ Training college intakes increased significantly during the early 1900 s, from 7000 places in 1903 to 12000 in $1910 .^{15}$ In addition, the establishment of 22 municipal colleges run by the LEAs after 1902 increased the accommodation available in all training colleges to 13,094 by $1914 .{ }^{16}$

Table 1. The certificated teaching body in $1899 .{ }^{17}$

\begin{tabular}{|c|c|c|c|c|c|c|c|}
\hline & \multicolumn{2}{|c|}{ No College Training } & \multicolumn{2}{|c|}{1 Year of Training } & \multicolumn{2}{|c|}{2 Years of Training } & \multirow[b]{2}{*}{ Total } \\
\hline & Number & $\%$ & Number & $\%$ & Number & $\%$ & \\
\hline Men & 6815 & 28.1 & 631 & 2.6 & 16,807 & 69.3 & 24,253 \\
\hline Women & 19,256 & 50.9 & 984 & 2.6 & 17592 & 46.5 & 37,832 \\
\hline
\end{tabular}

In general, the archives and record offices that were contacted for this study did not keep a record of the number of student records available. However, a recent report on the BFSS archives stated that they had processed ten thousand student applications for the nineteenth and early twentieth centuries into their CALM catalogue for the Borough College alone. ${ }^{18}$ The individual archives of the four former teacher training colleges that constitute Roehampton University also contain significant numbers of student records. ${ }^{19}$ The Colleges were Whitelands (Church of England), Southlands (Methodist), Digby Stuart (Roman Catholic) and the Froebel Institute (Humanist). There are approximately 4,450 student records for Whitelands' College covering the period 1841-1920, after which date the records are closed to third parties. ${ }^{20}$ LDTC was a relatively small college providing accommodation for 40 students until 1902 (Figure 2). In 1902 the College's capacity rose to 104 students. From 1895 the College also began to accept a small number of day students - by 1897 this amounted to 10 in all. ${ }^{21}$ There are just under 2,300 LDTC student cards covering the period 1862-1926. ${ }^{22}$

The types of training teacher records available vary significantly from college to college. For LDTC the only records that are specifically student related are found in the cards under discussion, some parchment documents and College magazine contributions. By contrast, the Durham Records Office contains student records for the Church of England Colleges of St. Bede (founded in 1838 for men) and St. Hild (founded in 1858 for women) and from the catalogue descriptions, the surviving documentation appears to contain a more comprehensive and wider-range of student related records. Examples of these records include: admissions and progress registers; student record sheets; reports on student performance; lists of certificates issued to students by the Board of Education and the details of scholarship examination candidates.

Taking all of these factors into consideration, it would not be unreasonable to conclude that there are a substantial number of student teachers' training records available to genealogists and family historians in archives around the two countries - even taking record loss into account.

\section{Finding a college-trained teacher in the census record}

Identifying a college-trained teacher from traditional genealogical sources alone is almost impossible. Occupational descriptions in the census like 'qualified', 'trained' or 'certificated' teacher can indicate a college-trained teacher. However, in this study, a minority of LDTC graduates identified themselves in this way at least once in the census records: $22 \%$ for Period 1 and $17 \%$ for Period 2. Additionally, Table 1 shows that there was a category of teachers who were certificated but who trained 'on the job' and not at a training college. A small group of LDTC students can be found resident at the college during the taking of a census. (The student body were resident at the College for the 1871, 1881 and 1911 censuses, while, for the 1891 and 1901 censuses, they were probably on their Easter break - leaving only the staff in residence.) In addition, this study, as well as More's study of the Cheltenham Colleges, found that students were drawn from all parts of the country (18 counties for both periods for LDTC). ${ }^{23}$ This, together with improved transport connections, means that there is no certainty that, for example, a teacher who was born in Lincolnshire and who was living there during a census was trained at LDTC. 


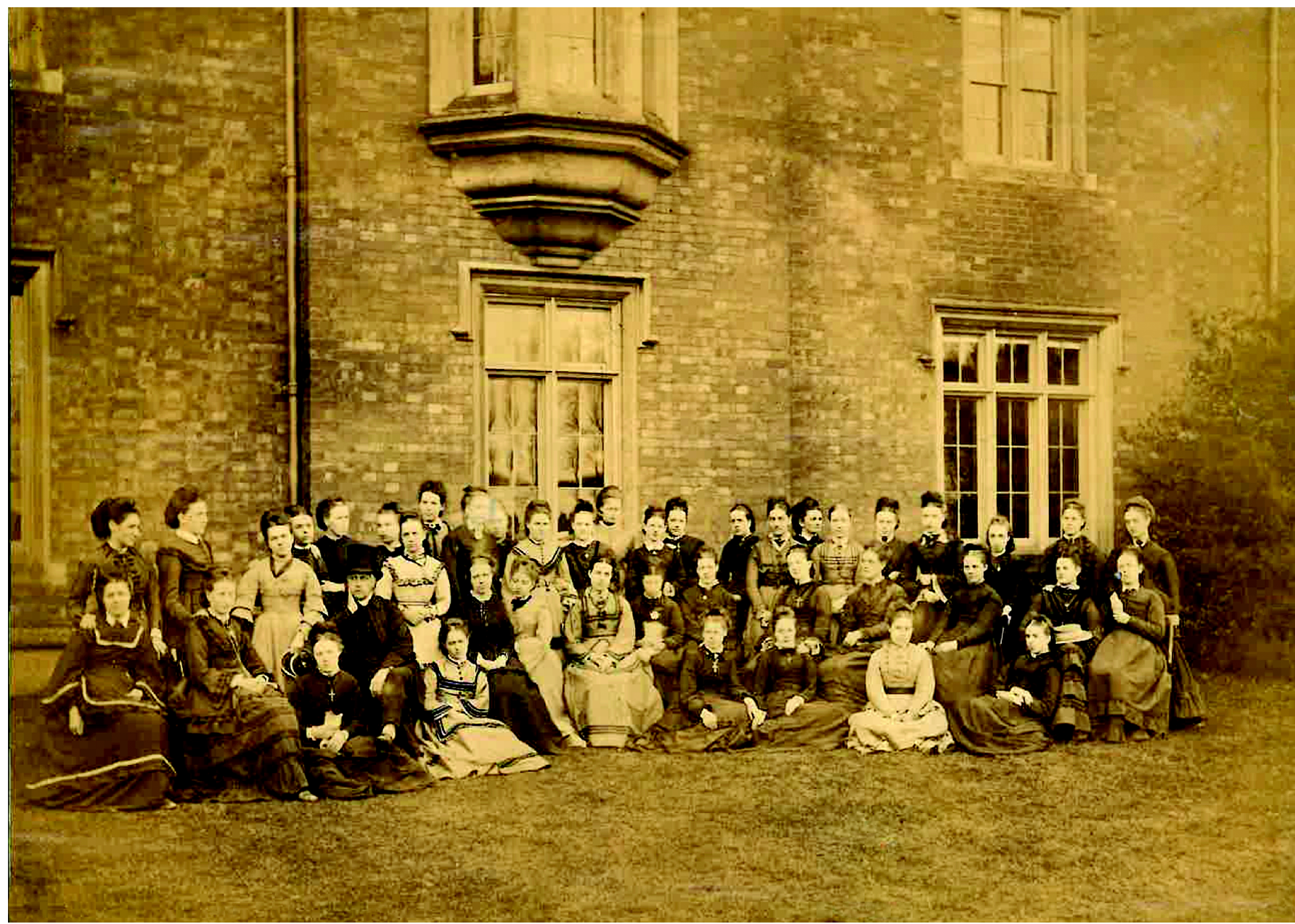

Figure 2. The oldest LDTC staff and student photograph, c.1868. Photograph used by the permission of the Bishop Grosseteste Archives. ${ }^{24}$

\section{Teacher-training and teacher records in online collections}

The only non-subscription website found in which teacher-training records can be accessed is the Brunel University London Archive website. The records of the BFSS are housed in this archive. The website features online transcriptions, in the form of spreadsheets, of the records of the men and women students that attended the Borough and Stockwell Colleges between 1804 and $1916 .{ }^{25}$ The transcripts include the student's addresses which can be helpful in identifying an individual's family.

Findmypast (FMP) provides two online collections that are helpful in providing information about teacher ancestors. These collections are cited on some websites as places to search for teacher records. ${ }^{26}{ }^{27}$ However, this study suggests that, although they do provide valuable information, the collections might not include the vast majority of the college-trained teaching body.

The first of these online repositories is the National School Admission Registers \& Log Books 1870-1914 collection. ${ }^{28}$ A reasonably thorough search showed that only 4 (4\%) of LDTC teachers could be located in this collection for Period 1. See Table 2. This low number may be impacted by the fact that the records only begin in 1870. The results were slightly better for Period 2 where 19 (17\%) of teachers were traced. Overall, in five cases $(2.4 \%)$, there were entries covering a teacher's time as a school pupil through to her apprenticeship and her role as a teacher. Despite the fact that many of the LDTC trained teachers were located in different parts of England, the records that were found were heavily weighted in favour of Lincolnshire schools (91\%). One possible reason for this imbalance, besides record loss, is the 'ongoing' nature of the project. ${ }^{29}$ 
Table 2. LDTC trained teachers in the FMP National School Admission Registers \& Log Books 1870-1914 Collection.

\begin{tabular}{lccc}
\hline & \multicolumn{2}{c}{$1862-1871$} & $1892-1901$ \\
\cline { 2 - 4 } & 194 & $\%$ & $/ 110$ \\
\hline Number of LDTC teachers located in the Collection & 4 & 4 & 19 \\
\hline Number of Schools & $1862-1871$ & $1892-1901$ \\
Number of Lincolnshire Schools & 4 & 29 \\
Total number of records found & 3 & 27 \\
\hline
\end{tabular}

The second FMP collection is the Teachers' Registration Council Registers, 1914-1948 (TRC) - the original records are held by the Society of Genealogists (SOG). These records list, among other information, the training college the teacher attended as well as their qualifications, postings and continued professional development. ${ }^{30}$ Teachers that began their careers as early as 1870 appear in this Collection. However, it is not a comprehensive record of the teachers who taught during the period because registration was not compulsory. For this study, these records were only helpful for students from the $2^{\text {nd }}$ period because by the time the TRC had begun to function, many of the Period 1 teachers had either stopped teaching, were coming to the end of their careers or were deceased. Altogether, 29 (26\%) of LDTC teachers signed up to the TRC. Figure 2 is an example of one of the TRC cards.

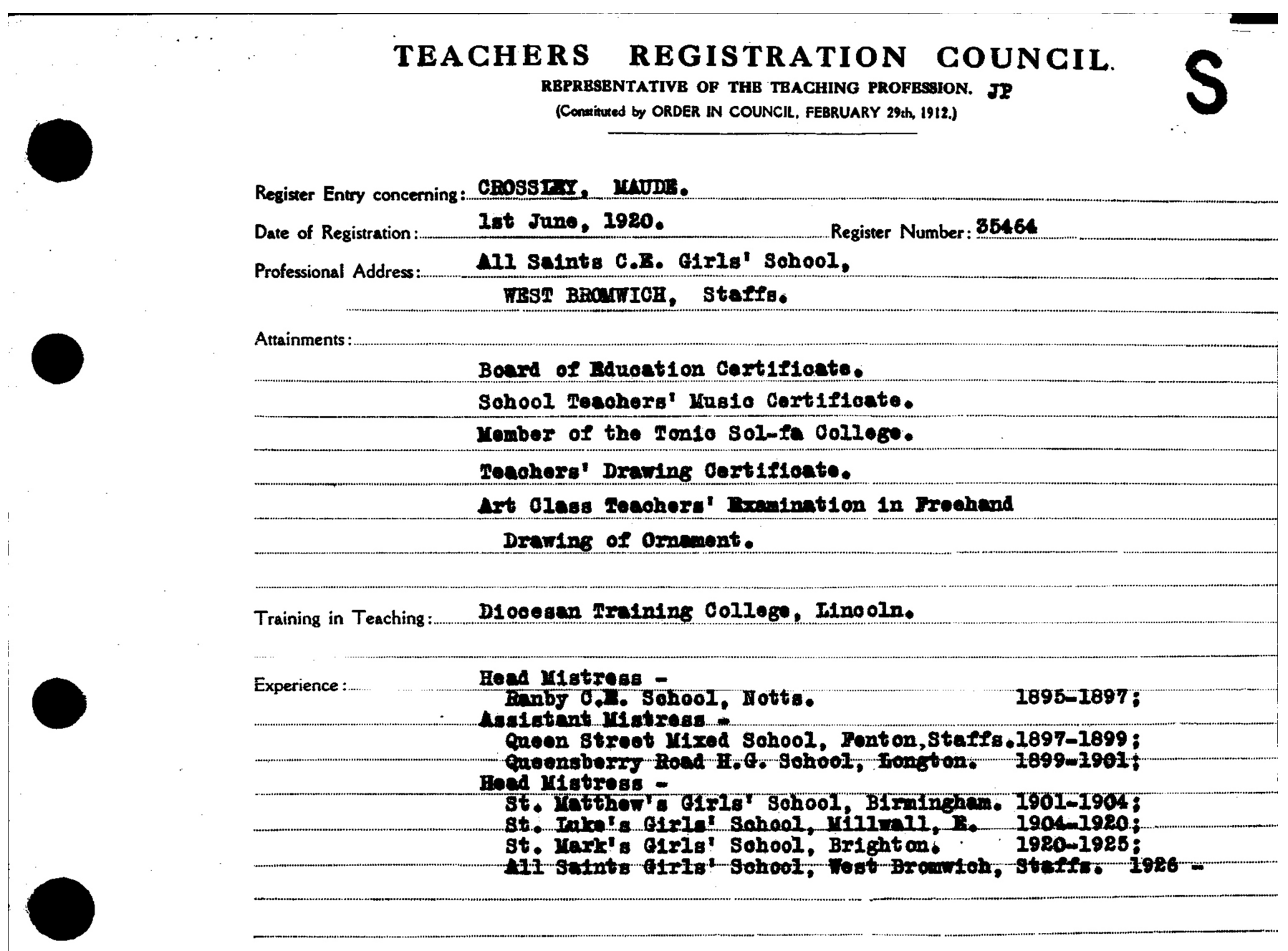

Figure 3. Teachers' Registration Council Record: CROSSLEY, Maude. Used with the permission of the Society of Genealogists. ${ }^{31}$ 
The issues highlighted with these online platforms suggest that the records of training colleges, if they have survived, are the most likely place to find information concerning ancestors who were teachers. An online, searchable index with some biographical detail, or images of the documents themselves, would be the best way of democratising teacher training records, as well as supplementing the previously mentioned FMP and SOG collections. Given the findings of this study regarding certified teachers in the census record, a searchable platform is required because it is improbable that a researcher would know which training college a teacher had attended.

\section{The LDTC student cards}

The LDTC cards contain the genealogical information and the descriptions and assessments of the students that left the College under the respective tenures of the first two college principals: Canon Hector Nelson (1862-1892) and Canon Alfred Rowe (1892-1912) - see Figure 4.

Many of the cards also contain post-college genealogical and career information. They were composed by the principals and were probably used as a reference for testimonial requests from past students. They may also have been used as quick reminders for occasions when the principals knew they would be meeting past students at events like the LDTC reunions. It is likely that the genealogical information was transcribed from the student application forms which no longer exist. ${ }^{32}$ From 1905, the cards became formalised and were pre-printed with the principal filling in the information. The card system was superseded by the adoption of student registers in 1926.

Occasionally, there is an indication that these student profiles were composed after the student had left the College and after some reflection as in the case of Eliza B: ${ }^{33}$

'I am led to regard her case as one of gradual declension. The only student who in 51/2 years spoke un-becomingly to me.'

Some of the cards provide evidence for the source of the information they contain. For example, Sarah Ann Holden's death was recorded on her card by the principal c. $1917:^{34}$

'Died early in 1917 at West Runton, W[est] Cromer - news sent by Mrs White. (Mary Watson 1867/8) 25, "Landsdowne" Stroud, Glo[ucester]s[hire]'.

It also shows that the source of the information was a previous student, who attended the College in 1867/8, which provides evidence, along with several other cards, that the family atmosphere encouraged by the first principal extended beyond the students' time at the College. ${ }^{35} 363738$

Eliza Thomazin's card provides evidence that Canon Nelson sometimes used information from correspondence he had received from the teachers' clergymen: ${ }^{39}$

'From Rev[eren]d Dodsworth's letter (10/6/64) infer that her work is excellent.'.

It is also very likely that the College Reunions, referred to on some of the cards, provided a rich source of information about past students. ${ }^{40} 4142$ Sometimes, the principals used the cards to record their frustration with a trend or an individual's actions. Canon Nelson was more inclined to write about his disappointments but here is one instance in which Canon Rowe expressed his objections to a student's conduct: $^{43}$

'Accepted a post in Dissenting Schools, without informing the Principal or in any way consulting him, after having received the benefits of two years training in a Church of England Training College.

Thoroughly competent Teacher, excellent disciplinarian, good student, but conduct not satisfactory in the above matter.'

Canon Nelson was wont to include subjective assessments of students for which it is much more difficult, if not impossible, to find supporting evidence. Occasionally, these comments appear to be quite blunt but they are generally more of the type found on Emma Atherton's card: ${ }^{44}$

'She was clever, \& like most Sheffield girls, a good singer, some considerable power, somewhat anaemic.'

These comments provide context even though it is through the eyes of one, possibly biased, observer.

Altogether the data on the two sets of cards encompasses a wide range of information that can be summarised generally into 4 different types. The word 'generally is used here because some of the information can span more than one category. Occupations and birth places, to give two examples, may be considered to be both genealogical and demographic information. None of the cards contains all of these elements and some fields are ignored completely in one set of cards: 


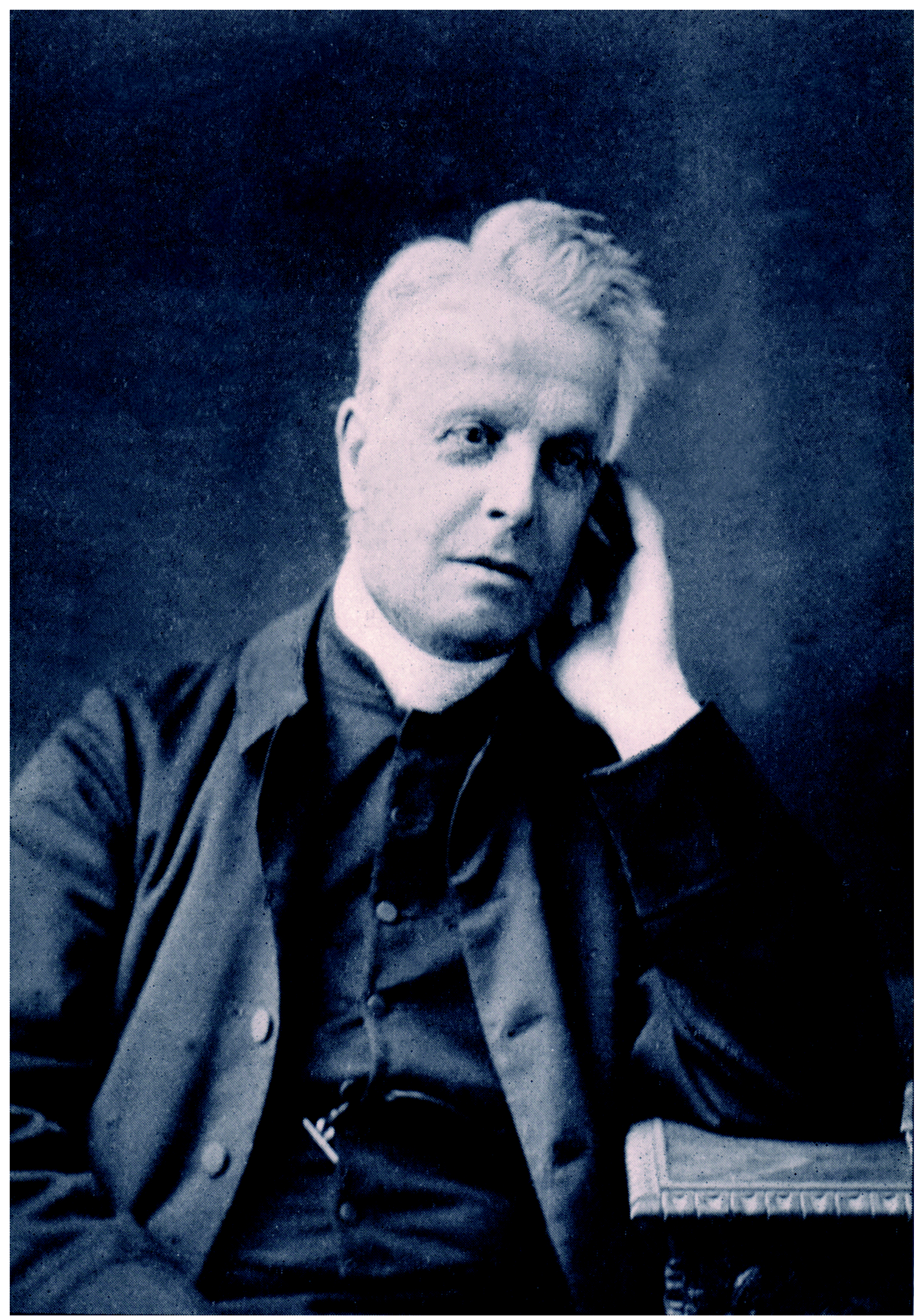

Figure 4. Canon Hector Nelson. Photograph used with the permission of the Bishop Grosseteste Archives. ${ }^{45}$ 


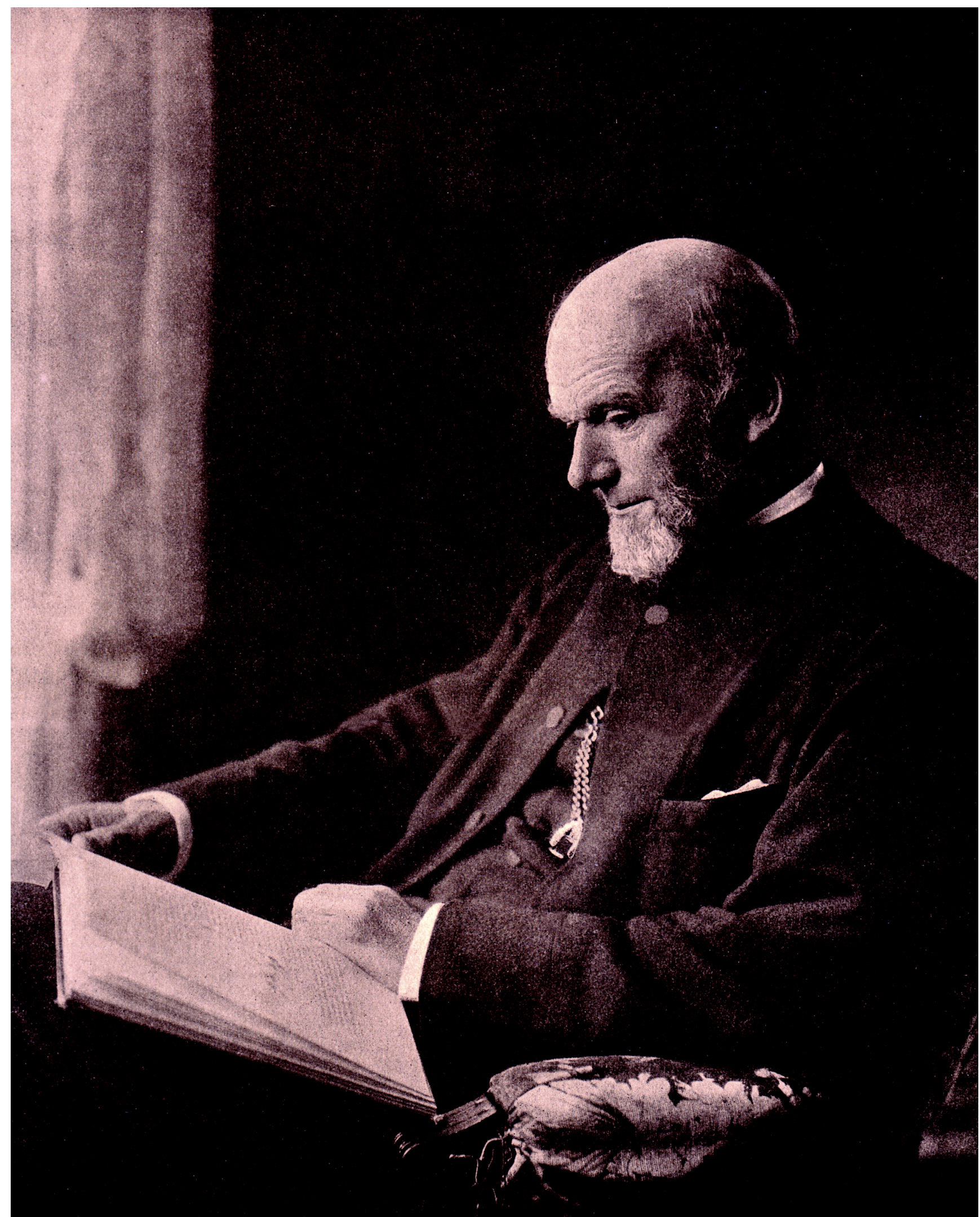

Figure 5. Canon Hector Nelson. Photograph used with the permission of the Bishop Grosseteste Archives. ${ }^{46}$ 


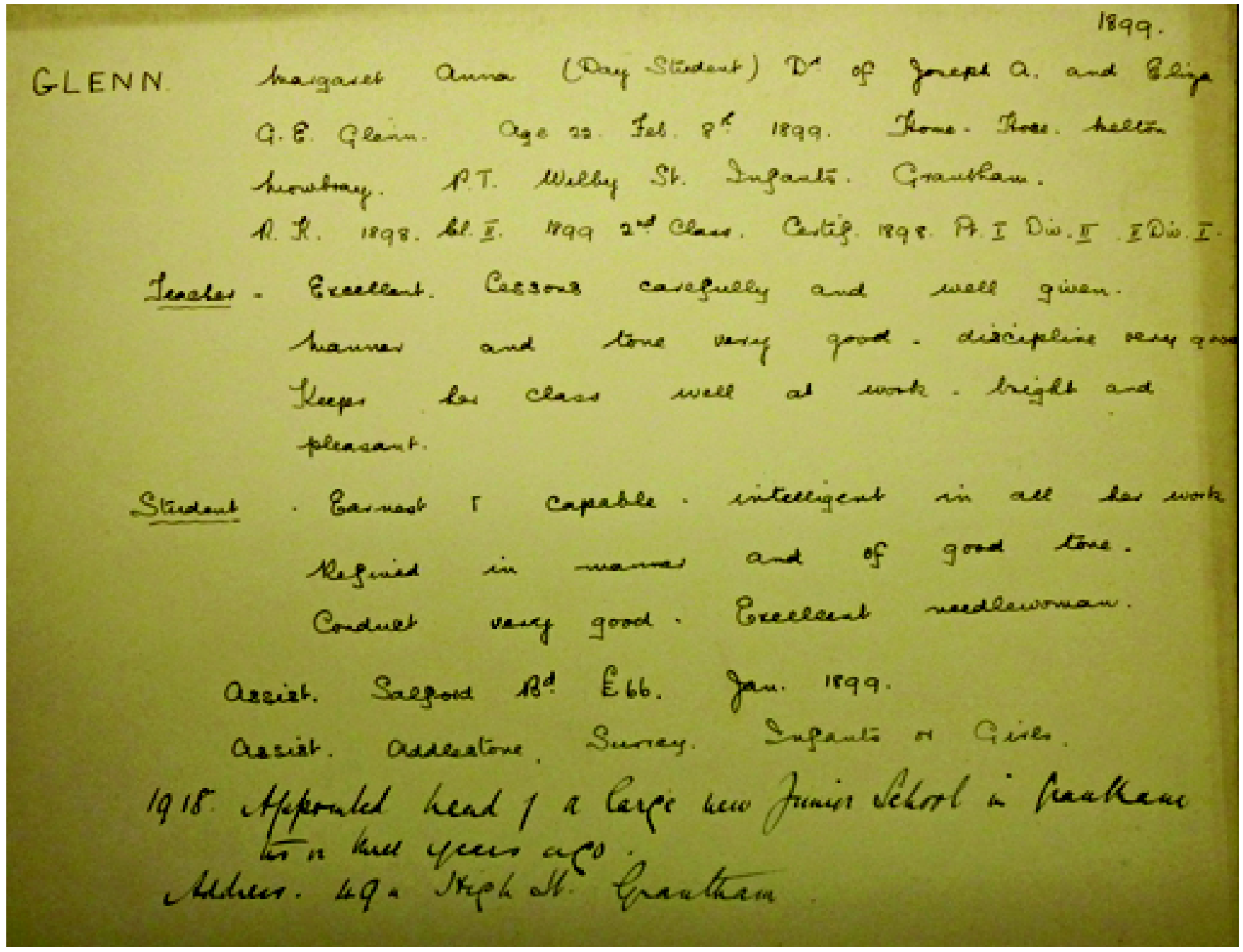

Figure 6. GLENN, Margaret Anna: her LDTC card. ${ }^{47}$

- Traditional genealogical information:

- Date of birth or age or a combination (only for 1892-1901)

- Christian name, second names and surname

- Parents' names

- Marriage, including a spouse's surname

- A mention of the teacher's children (only for 1862-1871)

- Familial relationships to other students (normally a sister or mother)

- Death with an occasional date

- Demographic information:

- A home address or the name of the student's home village, town or city

- The location of the first and sometimes subsequent teaching positions

- Father's, mother's and spouse's occupations (only for 1862-1871)

- Emigration or work undertaken overseas

- Salary (4\% for Period 1 and $77 \%$ for Period 2) 
- Training and Educational information:

- Whether or not they had been a pupil teacher and the school to which they were contracted

Examination results ( $20 \%$ for Period 1; $99 \%$ for Period 2) - these can also be found in the College magazines.

Strengths and weaknesses as a student and as a teacher

Whether a prize winner at the LDTC prize giving

Appointments to schools

Achievement of parchment

- Mention of success or failure at a specific school (only for 1862-1871)

The name of the student's home clergyman or the clergyman managing a specific school (only for 1862-1871)

Comments about or feedback from a clergyman (only for 1862-1871)

- Other:

- Comments about personal qualities or characteristics (only for 1862-1871)

- Family and marriage concerns (only for 1862-1871)

- Health problems (only for 1862-1871)

In general, the information recorded by the first principal, Canon Hector Nelson, is eclectic in nature, varies significantly in length and often contains confidential personal details and observations. By contrast, Canon Alfred Rowe's cards are characterised by a more methodical and less personal approach.

\section{Method}

A fifty percent sample was taken for both periods. Consequently, ninety-four and one hundred and ten records for Period 1 and Period 2 respectively, were selected for analysis. The details on each card were researched and checked for accuracy. From the research, a referenced, proforma-styled biography was created for each student. In addition, other information, mainly from census returns, Teachers' Registration Council cards, National School Admission Registers \& Log Books and probate records, was added to the biographies. Once the research had been completed, the information was entered onto the spreadsheet for comparison and analysis.

Below is an example of the process using Margaret Anna Glenn's card (Figure 6). She left LDTC in 1899 and the information from her card is summarised in Table 3.

Table 3. GLENN, Margaret, Anna: summary of her LDTC Card.

\begin{tabular}{ll}
\hline Name & GLENN, Margaret Anna \\
Status & Day Student \\
Age/Date of birth & Age 22 on 8 February 1899. \\
Home town/address & Melton Mowbray \\
Parents & Joseph A. and Eliza G.E. \\
Pupil Teacher & Welby St. Infants, Grantham, Lincolnshire. \\
Examination Results & 1898: Religious Knowledge, Class II1899: Religious Knowledge, 2 ${ }^{\text {nd }}$ Class1898: Certificate, Pt I Div II, Pt II Div I \\
Abilities as a teacher & Excellent. Lessons carefully and well given. Manner and tone very good - discipline very good keeps her class well at work - bright \\
& and pleasant. \\
Abilities as a student & Earnest and capable - intelligent in all her work. Refined in manner and of good tone. Conduct very good. Excellent needlewoman. \\
First Post & Assistant Salford Board Jan 1899. \\
Salary & $£ 66$ \\
Second Post & Assistant Addlestone, Surrey. Infants or Girls. \\
Third Post & $1918-$ Head of large new Junior School in Grantham. Two or three years ago. \\
Address & 49 High St., Grantham. \\
\hline
\end{tabular}

The information in Table 4 was derived from genealogical research. The Black text is information on her card confirmed during the research process; the blue text is extra information derived from the research process; the red text indicates a discrepancy or variation between the information on the card and the information found in other genealogical records. 
Table 4. Research Information - GLENN, Margaret Anna.

\begin{tabular}{ll}
\hline & \multicolumn{1}{c}{ GLENN, Margaret Anna - Research Information } \\
\hline Born & $1^{\text {st }}$ Q, 1877, Melton Mowbray, Leicestershire. \\
Name & GLENN, Margaret Hannah. \\
Baptism & 11 March 1877, Hose, Leicestershire. Hannah \\
Parents & Joseph Attewell and Eliza Georgiana Ellen. \\
Father's occupation & Grazier and Dairyman. Grazier. \\
Mother's occupation & No record. \\
Married & unmarried \\
Employment in census & \\
$\mathbf{1 8 9 1}$ & Scholar - Hose, Leicestershire \\
$\mathbf{1 9 0 1}$ & Certificated Elementary Teacher - Royden Villas, Chertsey, Surrey. \\
$\mathbf{1 9 1 1}$ & Schoolmistress, elementary - living in school house, Grantham, Lincolnshire. \\
$\mathbf{1 9 3 9}$ & School Teacher (retired) - The Bridge, Hose, Leicestershire. \\
TRC & She was a member of the Teachers' Registration Council. By 1923 she had been an assistant at three schools and Head Mistress at \\
Death & three schools. \\
\hline
\end{tabular}

No sources were found to confirm the unique information on Margaret's card, namely: her examination results (except for the College magazine); her abilities as a teacher; her abilities as a student; her first salary.

Margaret's demographic profile can also be established from this information. Some of the key features are as follows:

- She came from a skilled working class background. As an elementary teacher she was considered to be lower middle or intermediate class. ${ }^{48}$

- She was unmarried.

- Her probate effects represent a significant amount in today's money - $£ 205,100 .{ }^{49}$

- Her TRC card confirms her movements on her LDTC card from Salford to Surrey and then to Grantham. The census record confirms two of the locations - Surrey and Grantham.

The probate value of Margaret's estate, as well as her movements around the country, can be seen as proof of the increased independence and financial security of single career women. There is no obvious proof that her probate wealth was simply the result of inheritance money from her parents. No directory entries were found for Margaret. A single newspaper reference recorded that her death had brought to an end three hundred years of the Glenn family in the Hose, Leicestershire area. ${ }^{50}$

\section{Genealogical Findings}

\section{Births and Baptisms}

For Period 1, no dates of birth or ages were recorded on the cards whereas, for Period 2, only 19 dates of birth or ages were omitted. Research established whether the missing dates could be found or confirmed where these details had been recorded. A search was also made for baptism records to confirm the parents' names. Baptism records are also particularly relevant to these students as they would have had to have been either baptised, or to be able to show a confirmation certificate, to be accepted into an established church training college. ${ }^{51}$ Table 5 gives the percentages of the respective records that were found.

Table 5. Births and Baptism Records.

\begin{tabular}{lcccc}
\hline & \multicolumn{2}{c}{$1862-1871$} & & $1892-1901$ \\
\cline { 2 - 5 } & 194 & 0 & 91 & $\%$ \\
\hline LDTC cards: age or d.o.b. & 0 & 87 & 92 & 83 \\
Civil birth records & 82 & 72 & 55 & 84 \\
Baptisms & 68 & 18 & 23 & 50 \\
Births on Baptism record & 17 & 3 & 59 & 21 \\
Births on 1939 Register & 3 & 1 & 0 & 54 \\
Births on USA death record & 1 & & & 0 \\
\hline
\end{tabular}


The only discrepancies in the records for Period 1 are a small number of slightly late registration dates for civil births; this can be accounted for by the fact that parents had up to six weeks to register a birth without penalty. ${ }^{52}$ There were three late baptisms, but in only two of the cases was this likely to be motivated by the requirement for pupil teachers to be knowledgeable about the catechism and religious matters. ${ }^{53}$ Ellen Nolan was baptised aged sixteen and Hannah Best aged ten. ${ }^{54}{ }^{55}$ In seventeen cases, a second name was added by the online records and in only one case was a name on the baptism and civil birth records in conflict with a student's name on the cards. Myra Allenby was baptised Miriam and is also recorded as such on her civil birth record, but she seems to have preferred Myra throughout her life. ${ }^{56}$ No evidence was found for a twin.

For Period 2, there were only nine cards for which research provided further information like: a second name; a spelling variation; names where only initials were given. Therefore, overall, the details on both sets of cards reflect a high degree of coherence with online genealogical records.

\section{Parents}

Some of the cards had no parental information (Table 6).

Table 6. No parental information on LDTC cards.

\begin{tabular}{lcccc}
\hline & \multicolumn{2}{c}{$1862-1871$} & \multicolumn{2}{c}{$1892-1901$} \\
\cline { 2 - 5 } & 194 & $\%$ & 1110 & $\%$ \\
\hline No parental information on the cards & 18 & 19 & 43 & 40 \\
\hline
\end{tabular}

For Period 1, no instances were found where the baptism or census records conflicted with the parent information on the LDTC cards. There were two students whose parents' details presented some questions. Emma R.'s parents' names were not mentioned on her card. ${ }^{58}$ The only information for her birth comes from the census, but her approximate birth year and her place of birth are the only consistent details. In the 1851 census, she was listed as the six year old daughter of a fifty-two year old widower, John R., but in 1871 she was the daughter of what would have been her much older sister in $1851 .{ }^{59} 60$ The first census record could possibly have been a grandfather passing off an 'illegitimate' grandchild as his own or, alternately, perhaps by 1871, the older sister had adopted her younger sister as her own child.

Mary C.'s student card records her parents as, 'D[aughte]r. of Eliz[abeth] - has a stepfather - brought up by grandmother., ${ }^{61}$ Her baptism record shows that she was born out of wedlock. ${ }^{\prime 62}$ This could have prevented her from being a pupil teacher, '...except in cases of outstanding merit.... ${ }^{63}$ As mentioned above, she would not have had to submit a baptismal record if she could submit a confirmation certificate and considering there is no comment on her card, it can be concluded that she was able to produce the latter or was a 'case of outstanding merit'.

For Period 2 there were also a small number of discrepancies. Alice Child's mother was given as Edith on her card but as Jane on her baptism record. ${ }^{64} 65$ There is a marriage record for Alice's widower father in 1883 showing that he had a second marriage to an Edith, which explains this anomaly. ${ }^{66}{ }^{67}$ Elizabeth Emerson's mother was given as Marian on her card but Mary A in the census. ${ }^{68} 69$ This is probably a variation in spelling rather than a different name. Likewise, Mary Langham Thomson's mother was recorded as Annie Elizabeth at her baptism but on every other record was Fanny or Fanny Elizabeth. ${ }^{70} 71^{73}$ It is unlikely that these are two different people but it can't be discounted entirely. Annie Catherall is the only student who had someone other than her parents listed on her card. ${ }^{74}$ Instead, her uncle's name was given and according to an incomplete census record, she lived with him pre and post her attendance at LDTC. ${ }^{75} 77$ No records were found for her parents.

\section{Siblings}

Siblings are mentioned on a number of cards for both periods. A breakdown is provided in Table 7. Some of the cards, that recorded sisters, reference up to three siblings all of whom attended LDTC.

Table 7. Siblings on the LDTC cards.

\begin{tabular}{lcccccc}
\hline & Cards $/ 94$ & $\%$ & Total Siblings & Cards $/ 110$ & $\%$ & Total Siblings \\
\hline Sisters & 8 & 9 & 8 & 10 & 9 & 20 \\
Brothers & 2 & 2 & 2 & 1 & 1 & 1 \\
\hline
\end{tabular}


In the case of the brothers, no names were given but there are brief descriptions: 'soldier'; 'dying'; 'tea planter in India'. 787980 None of the brothers were conclusively located in the records. All of the sisters' names were given on the LDTC cards except for those of Mary Bannister, who were described as her 'three younger sisters'..$^{11}$ The three younger teacher sisters were found in the census record and the 1939 Register. ${ }^{82} 838485$ The records also revealed that there were another two younger sisters and two younger brothers in the family. This example, amongst others, shows that neither principal was concerned to provide details of all of the siblings related to a student. The siblings that are mentioned, however, are generally a valuable aid in identifying the family in the records.

\section{Marriages}

The numbers of marriages mentioned explicitly or implicitly on the cards, is recorded in Table 8.

Table 8. Marriages on the LDTC cards.

\begin{tabular}{lcccc}
\hline & $1862-1871$ & & $1892-1901$ & \\
\hline Marriages recorded on the cards & $/ 94$ & $\%$ & $/ 110$ & $\%$ \\
\hline
\end{tabular}

All of these marriages were confirmed in the records except that for Mary Collingwood (1870). The 1911 census record was used, in the Collingwood instance, to determine an approximate marriage year. More marriages came to light after research. For Period 1 and Period 2 a further eighteen and twenty marriage records, respectively, were found. There were also teachers for whom no definitive death or marriage record could be found; these teachers were considered to be neither married nor unmarried. The research results are summarised in Table 9

Table 9. Marriage records found.

\begin{tabular}{lcccc}
\hline & \multicolumn{2}{c}{$1862-1871$} & \multicolumn{2}{c}{$1892-1901$} \\
\cline { 2 - 5 } & 194 & $\%$ & 1110 & $\%$ \\
\hline Married & 67 & 71 & 53 & 48 \\
Unmarried & 18 & 19 & 50 & 45 \\
No marriage or death record found & 9 & 10 & 7 & 6 \\
\hline
\end{tabular}

The mode of recording the marriages was varied, but nearly all of the variety is provided by the 1862-1871 period. Emma Mason's card is an example of a straightforward recording, with detail about her husband and his occupation: ${ }^{86}$

'Married William Clarke, clerk at Philipp's Brewery.'

Lily Mottram's card is an example of a marriage suggested by a change of surname. In this case she had been married to an Albert Clark: ${ }^{87} 88$

'Mrs. B. Clark 18, Albany R[oa]d, Balby, Doncaster.'

The one anomaly is the initial B in B. Clark - no explanation was found for this and it is likely to have been a mistake.

A change of surname on a card did not necessarily mean that a marriage had taken place. For example, the entry for Clara Cuthbert reads, 'Married Mrs Mebhourne died', which suggests that her married name was Mebhourne. ${ }^{89}$ In fact, it is almost certain that Mebhourne is a reference to the Melbourne's who were a couple that Clara had been boarding with during the 1861 census. ${ }^{90}$ The research makes it clear that this entry is in note form and probably means that Mrs Melbourne was the source of the information about Clara's marriage and death. Clara had been married to Thomas Noden. ${ }^{91}$

Another unclear marriage entry was Fanny Watson's second marriage. It was recorded as 'Married again Welsh-Bookbinder'. This led to the question, "Is this 'Welsh the bookbinder' or 'a Welsh bookbinder'?" The records established that it was 'Welsh the bookbinder'. ${ }^{92}$ Another feature of this card was the mention of minor children. Canon Nelson sometimes referenced minor children but, as in this case, their names were not divulged. Nevertheless, it is helpful to be aware of this information when searching for records. 
The marriage information on the cards for both periods, except for the instances mentioned above, presents no major issues with regard to its accuracy. Even with respect to the cases featured above, there was nothing that couldn't be clarified by genealogical research.

\section{Deaths}

The number of deaths mentioned on the cards is recorded in Table 10. Only two precise dates were mentioned, both for 1862-1871, while the rest were given as: a year; before a certain year; as some other imprecise format. The records for all the card deaths were found online. Given the vague nature of some of the dates on the cards, there were no conflicts with the official records.

Table 10. Deaths on the LDTC cards.

\begin{tabular}{lccccc}
\hline & \multicolumn{2}{c}{$1862-1871$} & \multicolumn{2}{c}{$1892-1901$} \\
\cline { 2 - 5 } & 194 & $\%$ & $/ 110$ & $\%$ \\
\hline Deaths on LDTC Cards & 9 & 10 & 3 & 3 \\
\hline
\end{tabular}

In order to find out how many teachers were married, it was necessary to trace some of the teachers to their deaths to prove that they had been unmarried. Death records were also traced for married teachers. This was in order to provide data for the demographic study. The numbers of death and probate records found are recorded in Table 11.

Table 11. LDTC death and probate records.

\begin{tabular}{lccccc}
\hline & \multicolumn{2}{c}{$1862-1871$} & & \multicolumn{2}{c}{$1892-1901$} \\
\cline { 2 - 5 } & 194 & $\%$ & 76 & $\%$ \\
\hline Probate & 30 & 32 & 93 & 69 \\
Civil (UK) & 67 & 71 & 0 & 85 \\
Civil (USA) & 3 & 3 & 1 & 0 \\
Civil (Canada) & 1 & 1 & 16 & 1 \\
No death record & 23 & 24 & & 15 \\
\hline
\end{tabular}

\section{Demographic Analysis}

\section{Social Class}

The vast majority of LDTC students came from intermediate (lower middle class) or skilled working classes households for both periods (92\%). This figure is not too dissimilar to Coppock's study on the backgrounds of pupil teachers in Birmingham. Citing evidence from four census returns (1861-1891), Coppock found that $94.55 \%$ of pupil teachers came from the intermediate or skilled working classes. ${ }^{93}$

Copelman's states that, '...most women teacher's married men similar to themselves both in background and occupation. ${ }^{94}$ The spouses of former LDTC students were found to be predominantly from the lower middle and skilled working classes, broadly supporting Copelman's contention. It is also worth noting that for 1862-1871, 20(30\%) of the schoolmistresses married schoolmasters and for 1892-1901, it was a similar proportion of $13(27 \%)$.

Both More and Copelman have cautioned that it is a presumption to consider the class distinction between the lower middle classes and skilled working classes as being fixed. Quoting a study of social structures by Penn, More suggests that marriage patterns indicate a lack of barriers between these classes. ${ }^{95}$ Copelman states that class lines were blurred between the labour aristocratic and lower middle classes and that the two classes lived, despite their distinctive characteristics, in mixed communities all over Great Britain. ${ }^{96}$

\section{Marriage}

Table 8 shows that a higher proportion of teachers married for Period 1 than for Period 2. By comparison, in another growing profession favoured by women, a study of nurses at St George's Hospital in London, found that there was a more dramatic decline in married or widowed nurses, from $70 \%$ in 1851 to fewer than $10 \%$ by $1901 .{ }^{97}$ A similar trend occurred the General Hospital, Birmingham. ${ }^{98}$ This decline was strongly driven by the desire to employ younger nurses for economic reasons. Female Post Office clerks were forced to resign if they married and a study comparing them to teachers found that the clerks tended to choose their career over family. ${ }^{99}$ In the Civil Service, the marriage bar was applied very strictly. ${ }^{100}$ 
Copelman, Oram and Widdowson have advanced reasons; some based on oral evidence and teachers' written accounts, for a decline in the proportion of married teachers largely based on London teachers' experiences. Some of these reasons were:

- Some local education authorities began to apply a marriage bar on newly married teachers in the early 1900s that intensified in the interwar period. Widdowson and Oram have found evidence that this stopped teachers from marrying because of a loss of their own financial security. ${ }^{101} 102$

- Some teachers had not married because of the deaths of fiancés or men friends in the First World War. ${ }^{103}$ However, Oram has also argued that some teachers used this as an excuse to deflect from their unmarried state in a society that was intolerant and entertained prejudices towards spinster teachers. ${ }^{104}$

- Some teachers remained single because of a sense of duty towards supporting their families and being one of the central breadwinners. ${ }^{105}$ By contrast, Copelman states that some women carried on working after marriage to support their parents and other relatives. $^{106}$

These factors may explain the higher average marriage age for the Period 2 LDTC graduates in Table 12.

Table 12. LDTC mean marriage age.

\begin{tabular}{lcc}
\hline & $1862-1871$ & $1892-1901$ \\
\hline Mean Marriage Age (years) & 27.2 & 32.5 \\
\hline
\end{tabular}

Copelman records that one estimate in 1905 for the average age a woman teacher was married, was $27 .{ }^{107}$ This fits well with the average age that LDTC teachers married for the first period, but not for the Period 2 sample who married at a significantly more advanced age. A T-test applied to the data showed the difference in mean ages between the two periods is statistically significant. Census data also suggests that the LDTC teachers married later in their careers than women in general. From 1861 to 1911, the average marriage age for women increased from just over 25 to just over $26 .{ }^{108}$ Rates of celibacy among the LDTC teachers were also higher than the general population. Celibacy for the general population rose from about $11 \%$ in the 1861 census to $16 \%$ in the 1911 census. This in contrast to the LDTC rates of at least $19 \%$ and 45\% for Period 1 and Period 2 respectively. ${ }^{109}$

\section{Working patterns in the census record}

Working patterns, derived from the census records, indicate a wide range of narratives for LDTC married teachers and for those married with children (Table 13). Overall 27\% (Period1) and 19\% (Period 2) of married teachers, with or without children, carried on working (Table 13). By comparison, between 1891 and 1911, the proportion of married working women in the general population ranged from $9 \%$ to $11 \% .{ }^{110}$ This suggests that married LDTC teachers were more likely to be working than married women in the general population and lends support to Copelman's conclusion that, despite the twin pressures of household duties and opposition to the employment of married women, women teachers provided evidence that they could exist in two spheres. ${ }^{111}$

Table 13. Working patterns in the census records.

\begin{tabular}{lcccc}
\hline & \multicolumn{2}{c}{$1862-1871$} & \multicolumn{2}{c}{$1892-1901$} \\
\cline { 2 - 5 } & 167 & $\%$ & 153 & $\%$ \\
\hline Children, continued working & 12 & 18 & 3 & 6 \\
Childless, continued working & 6 & 9 & 7 & 13 \\
Children, stopped working & 35 & 52 & 17 & 32 \\
Childless, stopped working & 4 & 6 & 8 & 15 \\
Break from work, then resume & 6 & 9 & 3 & 6 \\
Incomplete or insufficient records. & 4 & 6 & 15 & 28 \\
\hline
\end{tabular}

For the period 1862-1871, a number of student cards record that teachers resumed working after a break. For example, in Figure 4.16, Rose Smith's husband's death was given as the reason she returned to work: ${ }^{112}$

'Married the blind organist of Heydown. Now in [18]82 left a widow with 5 children. I aim at getting her a post [18]82 and succeeded after a time in placing her at Wold Newton where in 1886 she gained her Parchment having been in College at a date when most of those in College were not yet born.

Parchment T. 1886 
This account is illustrated in the 1881 census where she was recorded married, had five children and no occupation; then, by the 1891 census, she was a widow, with no children and working as a school mistress. ${ }^{113} 114$ Other census records show some of her children were in orphanages or asylums. $^{115116}$

\section{Probate}

Probate was worked out as a value in today's terms, in order to give a sense of the wealth and financial independence of unmarried teachers in comparison to their married peers. ${ }^{117}$ Cummins, in an analysis of sixty million English probate and death records, has calculated that on average only $33 \%$ of the combined male and female population had a probate record between 1892 and $1992{ }^{118}$ The graduates of LDTC, 1862-1871, had a probate percentage of between $32 \%$ and $42 \%$ and for $1892-1901$ of between $69 \%$ and $81 \%$ (Table 14 ).

Table 14. Probate percentages of LDTC trained teachers.

\begin{tabular}{lcc}
\hline & As a \% of all 94 students & As a \% of 72 death records \\
\hline $1862-1871$ (30 Probate records) & 32 & 42 \\
\hline $1892-1901$ (76 Probate records) & As a \% of all 110 students & As a \% of 94 death records \\
\hline Both periods(106 Probate records) & 69 & 81 \\
\hline
\end{tabular}

These figures show that for both periods the LDTC graduates were more likely than the general population to leave a probate record. The figures also suggest that these teachers were more likely to be financially secure than women in general. This is particularly the case for Period 2 where the percentage of probate records for the LDTC teachers far exceeds that of the general population.

The mean value of probate effects (Table 15) shows that, ignoring the small sample size for Period 1, the gap between married and unmarried teachers closes significantly in Period 2. As a percentage, the measurement increases from unmarried effects being worth $40 \%$ of married for Period 1, to $84 \%$ for the second period. This enhances the view that school teaching was a good career for women who desired to maintain themselves independently from marriage. Also, teachers were equally or better paid than other occupations favoured by women like clerkships or nursing. ${ }^{119}$

Table 15. Probate - mean value of effects in today's terms.

\begin{tabular}{lcc}
\hline & $1862-1871$ (30 Records) & 1892-1901 (75 records) \\
\hline All records & $£ 91,483$ & $£ 117,256$ \\
Married & $£ 108,943$ & $£ 126,327$ \\
Unmarried & $£ 43,466$ & $£ 107,623$ \\
\hline
\end{tabular}

T-Tests were applied to the means in Table 15 and showed that there is a statistical significance in the case of unmarried probate between the two periods.

\section{Conclusion}

The genealogical information on the LDTC cards has been shown by this study to be essentially accurate. The problems identified with some of the details, like name variations and the confusing way in which the information is recorded, are similar to those that can be found in other sources readily used by genealogists. Therefore, the data on each card, just like any other record, should be evaluated by information derived from other sources before pronouncing on its reliability. In addition, the cards frequently offer much more information in one record than one would expect to find, some of which is unique.

The demographic study of these students contributes to similar studies that have been undertaken by historians and social historians. It is also valuable for genealogists in that it provides some context to the historical conditions under which these teachers operated and enriches their 'family history':

'What were your ancestors really like, what did they look like, what did they do, how were they affected by the great historical events and how did they live from day to day? Family history includes the research of all these matters. ${ }^{120}$ 
Some of the research has revealed similar results to other studies such as the social class the students and teachers inhabited. Some differences between the two periods have also been identified. For example, the significant decrease in the incidence of marriage and the increase in marriage age during Period 2; as well as the increase in probate effects' values for unmarried teachers for the same period. The LDTC cards show that teacher-training records can offer a reasonably accurate, rich source of genealogical and demographic information.

\section{Reference}

1. Hereinafter referred to as 'Period 1' and 'Period 2' respectively.

2. Board of Education Report, 1900-1901. p. 190 quoted in Shakoor, Akhtar. (1965) The training of teachers in England and Wales, 1900-1939. Unpublished PhD thesis, University of Leicester. https://ra.le.ac.uk/handle/2381/35670: accessed 30 March 2018. p. 37

3. Gillard, D. Education in England: a history. http://www.educationengland.org.uk/ history/chapter07.html: accessed 15 March 2018.

5. Gillard, D. Education in England: a history. Chapter 6. http://www.educationeng land.org.uk/history/: accessed 15 March 2018.

6. The BFFS also took advantage of state grants to finance their schools and training colleges.

7. Images: Photograph. South West View, Lincoln Dioscesan Training College. c.1897. Unknown photographer. Cover Photograph: Lincoln Diocesan Training College Magazine. Vol. 5. April 1897. Bishop Grosseteste University Archives, Lincoln.

4. British Library. Synopsis of the Forster Education Act 1870. https://www.bl.uk/: accessed 1 March 2020.

8. More, Charles. (1992) The Training of Teachers. 1847-1947: A History of the Church Colleges at Cheltenham. London: The Hambledon Press. p. 6.

9. Shakoor, Akhtar. (1965) The training of teachers in England and Wales, 1900-1939. Unpublished PhD thesis, University of Leicester. p. 6.https://lra.le.ac.uk/handle/ 2381/35670: accessed 30 March 2018.

10. Zebedee, D. H. J. (1962) Lincoln Diocesan Training College 1862-1962. Lincoln: Lincoln Diocesan Training College. p. 25.

11. Copelman, Dina Mira. (1996) London's Women Teachers: Gender Class and Feminism, 1870-1930. London and New York: Routledge. p. 72.

12. Lincoln Diocesan Training College. Student Record Cards. WILLIAMS, Martha. 1864. Bishop Grosseteste University Archives, Lincoln. Collection: Student record cards 1862-1904.

13. House of Commons. (1888) Royal Commission to inquire into the Working of Elementary Education Acts (England and Wales): Information in Answer to Inquiries by Circular to Principals of Training Colleges in England and Wales. House of Commons Parliamentary Papers. London: House of Commons. p. 141. https:// parlipapers.proquest.com/: accessed 12 May 2019.

14. Adapted from Tropp, Asher. (1957) The School Teachers: The Growth of the Teaching Profession in England And Wales from 1800 to the Present Day. London: Heinemann. p. 117. https://archive.org/: accessed 20 March 2019.

15. Tropp, op. cit. p. 188.

16. Shakoor, op. cit. p. 215.

17. Adapted from: Tropp, op. cit. p. 117.

18. Brunel University (2019) BFFS Archives Annual Report 2019. London: Brunel University. p. 4. https://www.brunel.ac.uk: accessed 4 August 2019.

19. University of Roehampton. University of Roehampton Archives Catalogue. https:// calmview.roehampton.ac.uk/: accessed 15 February 2020.

20. Bentley, Gemma. (2020) Re: Response concerning the student records at the Whitelands Archive. E-mail to author, 14 October, 12: 20.

21. Zebedee, op. cit. p. 69.

22. Moyes, Guenever. (2020) Re: Response concerning the student cards at the Bishop Grosseteste University Archive. E-mail to author, 14 October, 12: 20.

23. More, op. cit. p. 105.

24. Images: Photograph. Staff and Students. c.1868. Unknown photographer. College Photograph Album 19-20c. Bishop Grosseteste University Archives, Lincoln.

25. Brunel University London. (2019) British and Foreign School Society (BFSS) Archive: Transcriptions. https://www.brunel.ac.uk/about/Archives/BFSS/Transcripts: accessed 5 February 2019.

26. UCL Institute of Education. (2017) Researching family history: Useful records and where to find them. https://libguides.ioe.ac.uk: accessed 20 January 2019.

27. GenGuide. Teacher Records. https://www.genguide.co.uk/source/teacher-recordseducation-amp-occupations-including-ireland-amp-scotland/209/: accessed 20 January 2019.

28. Findmypast. (2019) National School Admission Registers \& Log Books 1870-1914 https://www.findmypast.co.uk: accessed 20 January 2019

29. Findmypast. (2020) National School Admission Registers. https://www.findmypast.co. uk/: accessed 15 October 2020.

30. Findmypast. (2019) Teachers' Register Council Registers 1914-1948. https://www. findmypast.co.uk: accessed 20 January 2019

31. Teachers' Registration Council. 1 February 1923. CROSSLEY, Maude. Membership no: 35464. Collection: Teachers' Register Council Registers 1914-1948. http://www. sog.org.uk/: accessed 14 April 2019.

32. A copy of the application form can be found in: House of Commons. (1888) Royal Commission to inquire into the Working of Elementary Education Acts (England and Wales): Information in Answer to Inquiries by Circular to Principals of Training Colleges in England and Wales. House of Commons Parliamentary Papers. London: House of Commons. p. 140. https://parlipapers.proquest.com/: accessed 12 May 2019.

33. Lincoln Diocesan Training College. Student Record Cards. B., Eliza. 1863. Bishop Grosseteste University Archives, Lincoln. Collection: Student record cards 1862-1904.

34. Lincoln Diocesan Training College. Student Record Cards. HOLDEN, Sarah Ann. 1867. Bishop Grosseteste University Archives, Lincoln. Collection: Student record cards 1862-1904.

35. Zebedee, op. cit. p. 17

36. Lincoln Diocesan Training College. Student Record Cards. WRIGHT, Sarah Ann 1867. Bishop Grosseteste University Archives, Lincoln. Collection: Student record cards 1862-1904.

37. Lincoln Diocesan Training College. Student Record Cards. MAGEE, Margaret. 1870. Bishop Grosseteste University Archives, Lincoln. Collection: Student record cards 1862-1904.

38. Lincoln Diocesan Training College. Student Record Cards. GREGORY, Alice Ann. 1871. Bishop Grosseteste University Archives, Lincoln. Collection: Student record cards 1862-1904.

39. Lincoln Diocesan Training College. Student Record Cards. THOMAZIN, Eliza. 1862 Bishop Grosseteste University Archives, Lincoln. Collection: Student record cards 1862-1904.

40. Lincoln Diocesan Training College. Student Record Cards. CARTER, Lucy. 1864. Bishop Grosseteste University Archives, Lincoln. Collection: Student record cards 1862-1904.

41. Lincoln Diocesan Training College. Student Record Cards. COOPER, Annie Maria. 1866. Bishop Grosseteste University Archives, Lincoln. Collection: Student record cards 1862-1904.

42. Lincoln Diocesan Training College. Student Record Cards. BARTON, Emma. 1867. Bishop Grosseteste University Archives, Lincoln. Collection: Student record cards 1862-1904.

43. Lincoln Diocesan Training College. Student Record Cards. B., Alice. 1893. Bishop Grosseteste University Archives, Lincoln. Collection: Student record cards 1862-1904.

44. Lincoln Diocesan Training College. Student Record Cards. ATHERTON, Emma. 1862. Bishop Grosseteste University Archives, Lincoln. Collection: Student record cards 1862-1904.

45. Images: Photograph. Canon Hector Nelson. c.1892. Unknown photographer. Collection: University Photograph Collection, Box 3.Bishop Grosseteste University Archives, Lincoln.

46. Images: Photograph. Canon Alfred Rowe. c.1912. Unknown photographer. Collection: University Photograph Collection, Box 3. Bishop Grosseteste University Archives, Lincoln.

47. Lincoln Diocesan Training College. Student Record Cards. GLENN, Margaret Anna 1899. Bishop Grosseteste University Archives, Lincoln. Collection: Student record cards 1862-1904.

48. Class descriptors as found in: Coppock, David A. (1997) Respectability as a Prerequisite of Moral Character: The Social and Occupational Mobility of Pupil Teachers in the Late Nineteenth and Early Twentieth Centuries. The Journal of the History of Education Society. 26(2). https://www.tandfonline.com: accessed 20 January 2019.

49. Measuring worth.com. Purchasing Power of British Pounds from 1270 to Present. https://www.measuringworth.com/calculators/ppoweruk/: accessed 20 June 2019.

50. Grantham Journal. (1950) Last of 300-years-old Hose family: Passing of Miss M. A. Glenn. Grantham Journal.6 October. p. 10f. Collection: British Newspapers. http:// www.findmypast.co.uk: accessed 28 September 2019. 
51. House of Commons. (1888) Royal Commission to inquire into the Working of Elementary Education Acts (England and Wales): Information in Answer to Inquiries by Circular to Principals of Training Colleges in England and Wales. House of Commons Parliamentary Papers. London: House of Commons. p. 140. https:// parlipapers.proquest.com/: accessed 12 May 2019.

52. Annal, Dave and Collins, Audrey. (2012) Birth, marriage and death records: a guide for family historians. Barnsley: Pen and Sword Books. ISBN: 978-1848845725. p. 48

53. Tropp, op. cit. p. 22.

54. Lincoln Diocesan Training College. Student Record Cards. NOLAN, Ellen. 1865. Bishop Grosseteste University Archives, Lincoln. Collection: Student record cards 1862-1904.

55. Lincoln Diocesan Training College. Student Record Cards. BEST, Hannah. 1865 Bishop Grosseteste University Archives, Lincoln. Collection: Student record cards 1862-1904.

56. Baptisms (PR) England. West Knigton, Dorset,. 19 April 1846. ALLENBY, Miriam. FHL Source film no:1239202. [Transcription] Collection: England Births and Christenings, 1538-1975. https://www.ancestry.co.uk: accessed 14 April 2019.

57. Testamentary records. England. 31 May 1920. DAWSON, Myra. Principal Probate Registry. Calendar of the grants of probate . p. 53. Collection: England \& Wales, National Probate Calendar, 1858-1966. http://www.ancestry.co.uk: accessed 20 March 2019

58. Lincoln Diocesan Training College. Student Record Cards. R., Emma. 1866. Bishop Grosseteste University Archives, Lincoln. Collection: Student record cards 1862 1904

59. Census records. England. Birmingham, Staffordshire. 30 March 1851. R., Emma. PN 2058. FL 490. SN 50. ED 19. p. 45. http://www.ancestry.co.uk: accessed 4 January 2019.

60. Census records. England. Hulme, Lancashire. 2 April 1871. R., Emma. PN 4003. FL 152. SN234. ED 56. p. 45. http://www.ancestry.co.uk: accessed 4 January 2019.

61. Lincoln Diocesan Training College. Student Record Cards. C., Mary. 1870. Bishop Grosseteste University Archives, Lincoln. Collection: Student record cards 1862 1904

62. Baptisms (PR) England. Grantham, Lincolnshire. 7 December 1849. C., Mary. Collection: Lincolnshire Baptisms. https://findmypast.co.uk: accessed 14 April 2019.

63. Tropp, op. cit. p. 22

64. Lincoln Diocesan Training College. Student Record Cards. CHILD, Alice Jane. 1899. Bishop Grosseteste University Archives, Lincoln. Collection: Student record cards 1862-1904.

65. Baptisms (PR) England. Leeds, Yorkshire. 10 November 1877 (and birth 18 September 1877). CHILD, Alice Jane West Yorkshire, England, Church of England Births and Baptisms, 1813-1910. https://www.ancestry.co.uk: accessed 14 April 2019

66. Marriages (PR) England. Guiseley, Yorkshire. 24 July 1869. CHILD, James and HARDY, Jane. Collection: West Yorkshire, England, Church of England Marriages and Banns, 1813-1935. https://ancestry.co.uk: accessed 14 April 2019.

67. Marriages (PR) England. Great Horton, Yorkshire. 22 December 1883. CHILD, James and MASON, Edith. Collection: West Yorkshire, England, Church of England Marriages and Banns, 1813-1935. https://ancestry.co.uk: accessed 14 April 2019.

68. Lincoln Diocesan Training College. Student Record Cards. EMERSON, Elizabeth 1893. Bishop Grosseteste University Archives, Lincoln. Collection: Student record cards, 1862-1904.

69. Census records. England. Bromley St Leonard. 3 April 1881. EMERSON, Mary A. PN 496. FL 108. ED 14. p. 32. http://www.ancestry.co.uk: accessed 4 January 2019.

70. Baptisms (PR) England. Rugby, Warwickshire. 27 August 1876. THOMSON, Mary Annie Langham. Collection: Warwickshire, England, Church of England Baptisms, 1813-1910. https://ancestry.co.uk: accessed 14 April 2019.

71. Lincoln Diocesan Training College. Student Record Cards. THOMPSON, Marainne Langham. 1898. Bishop Grosseteste University Archives, Lincoln. Collection: Student record cards, 1862-1904.

72. Census records. England. Rugby, Warwickshire. 5 April 1891. THOMSON, Fanny E. PN 18597. FL 11. p. 45. http://www.ancestry.co.uk: accessed 4 January 2019.

73. Census records. England. Rugby, Warwickshire. 31 March 1901. THOMSON, Fanny E. PN 2918. FL 21. SN 191. ED 27. p. 45. http://www.ancestry.co.uk: accessed 4 January 2019.

74. Lincoln Diocesan Training College. Student Record Cards. CATHERALL, Annie. 1893. Bishop Grosseteste University Archives, Lincoln. Collection: Student record cards 1862-1904.

75. Census records. England. St John, Cheshire. 3 April 1881. CHESWORTH, Thomas (head). PN 3554. FL 13. ED 5. p. 5. http://www.ancestry.co.uk: accessed 4 January 2019
76. Census records. England. Chester, Cheshire. 5 April 1891. CHESWORTH, Thomas (head). PN 2861. FL 107. http://www.ancestry.co.uk: accessed 4 January 2019.

77. Census records. England. Chester, Cheshire. 31 March 1901. CHESWORTH, Thomas (head). PN 3368. FL 104. SN137. ED 04. p. 23. http://www.ancestry.co.uk: accessed 4 January 2019

78. Lincoln Diocesan Training College. Student Record Cards. BUCKLEY, Bessie. 1864 Bishop Grosseteste University Archives, Lincoln. Collection: Student record cards 1862-1904.

79. Lincoln Diocesan Training College. Student Record Cards. CARTER, Lucy. 1864 Bishop Grosseteste University Archives, Lincoln. Collection: Student record cards 1862-1904.

80. Lincoln Diocesan Training College. Student Record Cards. ROBINSON, Elizabeth 1893. Bishop Grosseteste University Archives, Lincoln. Collection: Student record cards 1862-1904.

81. Lincoln Diocesan Training College. Student Record Cards. BANNISTER, Mary. 1901 Bishop Grosseteste University Archives, Lincoln. Collection: Student record cards 1862-1904.

82. Census records. England. Scunthorpe, Lincolnshire. 5 April 1891. BANNISTER, Bamford (head). PN 2627. FL 151. http://www.ancestry.co.uk: accessed 4 January 2019.

83. Census records. England. Scunthorpe, Lincolnshire. 31 March 1901. BANNISTER, Bamford (head). PN 3103. FL 104. SN247. ED 13. p. 39. http://www.ancestry.co.uk: accessed 4 January 2019.

84. Census records. England. Scunthorpe, Lincolnshire. 2 April 1911. BANNISTER, Bamford (head). PN 20083. ED 16. http://www.ancestry.co.uk: accessed 4 January 2019

85. 1939 Register, England. Scunthorpe M.B., Lincolnshire. BANNISTER, Blanche E. 29 September 1939. Schedule 111. RG101/6428D/023/26. National Archives (Great Britain), Kew, England. Collection: 1939 Register. http://www.findmypast.co.uk: accessed 20 April 2019.

86. Lincoln Diocesan Training College. Student Record Cards. MASON, Emma. 1863 Bishop Grosseteste University Archives, Lincoln. Collection: Student record cards 1862-1904.

87. Lincoln Diocesan Training College. Student Record Cards. MOTTRAM, Lily Alice. 1899. Bishop Grosseteste University Archives, Lincoln. Collection: Student record cards 1862-1904.

88. Marriages index (CR) England \& Wales. RD: Market Harborough, Leicestershire. $1^{\text {st }}$ Q., 1910. CLARK, Albert and MOTTRAM, Lilly Alice. Vol. 7a. p. 43. [Transcription] Collection: England and Wales Civil Registration Marriage Index, 1837-1915. http:// ancestry.co.uk/: accessed 11 February 2019.

89. Lincoln Diocesan Training College. Student Record Cards. CUTHBERT, Clara. 1865. Bishop Grosseteste University Archives, Lincoln. Collection: Student record cards 1862-1904.

90. Census records. England. Eastgate St Peter, Lincolnshire. 7 April 1861. MELBOURNE, David (head). PN 2361. FL 26. SN 29. ED 24. p. 6. http://www.ancestry.co.uk: accessed 4 January 2019.

91. Marriages index (CR) England \& Wales. RD: Lincoln, Lincolnshire. 1st Q.,1876. NODEN, Thomas and CUTHBERT, Clara Annie. Vol. 7a. p. 641. [Transcription] Collection: England and Wales Civil Registration Marriage Index, 1837-1915. http://ancestry.co.uk/: accessed 11 February 2019

92. Marriages index (CR) England \& Wales. RD: Caistor, Lincolnshire. $3^{\text {rd }}$ Q., 1887. WELSH, Charles and FRANCIS, Fanny. Vol. 7a. p. 1001. [Transcription] Collection: England and Wales Civil Registration Marriage Index, 1837-1915. http://ancestry.co. uk/: accessed 11 February 2019.

93. Mean value derived from Table 1, Coppock, op. cit. p. 176

94. Copelman, op. cit. p. 180.

95. Penn, R. (1985) Skilled Workers in the Class Structure. Cambridge: Cambridge University Press. chs. 10-12. quoted in More, op. cit. p.116

96. Ibid . pp.34-36.

97. Hawkins, Sue. (2010) Nursing and Women' Labour in the Nineteenth Century: The Quest for Independence. Abingdon. Routledge. No page. https://books.google.co. uk/: accessed 20 October 2019.

98. Wildman, S. (1999) The Development of Nursing at the General Hospital, Birmingham, 1779-191. International History of Nursing Journal. 4(3). pp. 56-65. In: Hawkins, Sue. (2010) Nursing and Women' Labour in the Nineteenth Century: The Quest for Independence. Abingdon. Routledge. No page. https://books.google.co. uk/: accessed 20 October 2019.

99. London Teacher. 26 April 1912. p. 328. In: Copelman, Dina Mira. (1996) London's Women Teachers: Gender Class and Feminism, 1870-1930. London and New York: Routledge. p. 194

100. Understanding the Civil Service. Women in the Civil Service-History. https://www. civilservant.org.uk/: accessed 20 March 2020. 
101. Widdowson, F. (1980) Going Up Into the Next Class: Women and Elementary Teacher Training 1840-1914. London: Hutchison. p. 66.

102. Oram, Alison Margaret. (1996) Women Teachers in State Schools in England and Wales 1900-1939: The Development of Feminist Allegiance and Political Strategies. Unpublished PhD Thesis, London School of Economics and Political Science. p. 110. http://etheses.Ise.ac.uk/: accessed 4 December 2019.

103. Widdowson, op. cit. p. 66

104. Oram, op. cit. p. 299.

105. Oram, op. cit. p. 96.

106. Copelman, op. cit. p.186.

107. Greater London Record Office. (1906) Applications for Promotions, 1905. Reference: EO/STA/2/12. In: Copelman, Dina Mira. (1996) London's Women Teachers: Gender Class and Feminism, 1870-1930. London and New York: Routledge. p. 180.

108. University of Cambridge. Age at Marriage. Populations Past - Atlas of Victorian and Edwardian Population. https://www.populationspast.org: accessed 30 September 2019.

109. University of Cambridge. Celibacy. Populations Past - Atlas of Victorian and Edwardian Population. https://www.populationspast.org: accessed 30 September 2019 .

110. Ibid .

111. Copelman, op. cit. p. 195
112. Lincoln Diocesan Training College. Student Record Cards. SMITH, Rose Margaret. 1868. Bishop Grosseteste University Archives, Lincoln. Collection: Student record cards 1862-1904.

113. Census records. England. Haydor, Lincolnshire. 3 April 1881. CRAXFORD, William J (head). PN 3234. FL 89. ED 26. p. 3. http://www.ancestry.co.uk: accessed 4 January 2019.

114. Census records. England. Wold Newton, Lincolnshire. 5 April 1891. CRAXFORD, Rose (head). PN 2620. FL 46. http://www.ancestry.co.uk: accessed 4 January 2019.

115. Census records. England. Wanstead, Essex. 5 April 1891. CRAXFORD, Percy Edward and Lionel George. PN 7352. FL 126. http://www.ancestry.co.uk: accessed 4 January 2019.

116. Census records. England. Coulsdon, Surrey. 5 April 1891. CRAXFORD, Agnus Eliza. PN 600. FL 105. http://www.ancestry.co.uk: accessed 4 January 2019.

117. Measuring worth.com., op. cit.

118. Cummins, Neil. (2019) Where is the Middle Class? Inequality, Gender and the Shape of the Upper Tail from 60 million English Death and Probate Records, 1892-2016. http://neilcummins.com: accessed 28 September 2019. p. 12

119. Oram, op. cit. pp. 48-58.

120. Herber, Mark D. (2004) Ancestral trails: the complete guide to British genealogy and family history. $2^{\text {nd }}$ ed. Stroud: Sutton. p. xvi.

\section{ABOUT THE AUTHOR}

Colin's ancestry includes individuals from English, Scottish and German settler groups to South Africa. He is a former teacher and has a BA Honours (History) from the University of South Africa and a MSc in Genealogical Studies from Strathclyde. 